\title{
ANALISIS KEMAMPUAN KOMUNIKASI MATEMATIS SISWA PADA MATERI PENYAJIAN DATA DI KELAS VII MTS ISLAMIYAH MEDAN T.P 2017/2018
}

\author{
Oleh: \\ Nursyahbany Sitorus Pane*, Indra Jaya**, Mara Samin Lubis*** \\ * Mahasiswa Jurusan Pendidikan Matematika FITK UIN-SU Medan \\ **Dosen Tetap Jurusan Pendidikan Matematika FITK UIN-SU Medan \\ *** Dosen Tetap Jurusan Pendidikan Matematika FITK UIN-SU Medan \\ Jl. Williem Iskandar Pasar V Medan Estate \\ E-mail:*nursyahbany.sitopan@gmail.com, **indradoktor@gmail.com, \\ ***marasmin@yahoo.com
}

\begin{abstract}
:
The ability of students' mathematical communication is an aspect that needs to be developed in the learning of mathematics. The purpose of this study is to obtain a description of the mathematical communication ability of class VII students in learning mathematics. This research is a qualitative research. The subject of this research is 6 students of class VII-AMTs Islamiyah Medan who come from high-ability students, medium-skilled students, and low-ability students. Data collection techniques used are observation, interview, and documentation. To know how far students' mathematical communication ability is measured based on indicator of mathematical communication ability ie (1) Ability to express mathematical ideas through oral, written, and demonstrate and visualize it; (2) The ability to understand, interpret, and evaluate mathematical ideas in writing, as well as in other visual forms; (3) The ability to use terms, mathematical notations and structures to present ideas, describe relationships with situational models. The results showed (1) subjects with high ability to have good enough mathematical communication ability on each indicator both indicator 1, 2 and 3; (2) medium-sized subjects also have good mathematical communication skills in indicators 1 and 2 and less well in indicator 3; (3) low-ability subjects have poor mathematical communication skills on each indicator.
\end{abstract}

Keywords:

Mathematical Communication, Mathematics Learning

\section{A. Pendahuluan}

Pendidikan adalah usaha sadar dan terencana untuk mewujudkan suasana belajar dan proses pembelajaran agar peserta didik secara aktif mengembangkan potensi dirinya untuk memiliki kekuatan spiritual keagamaan, pengendalian diri, kepribadian, kecerdasan, ahlak mulia, serta keterampilan yang diperlukan dirinya, masyarakat, bangsa dan negara (Komariyah, 2015: 20). Pendidikan bertujuan untuk menumbuhkembangkan potensi manusia agar menjadi manusia dewasa, 
beradab dan bermoral sehingga akan membawa perubahan sikap, perilaku dan nilai-nilai pada individu, kelompok dan masyarakat. Salah satu upaya untuk mencapai tujuan itu adalah melalui pelajaran Matematika.

Matematika merupakan salah satu mata pelajaran yang memiliki peranan penting dalam mengembangkan potensi yang dimiliki siswa. Matematika merupakan salah satu ilmu yang mendasari perkembangan ilmu pengetahuan dan teknologi informasi serta mempunyai peran penting dalam pengembangan daya pikir siswa.Selain itu, matematika juga merupakan sarana berpikir logis, analitis dan sistematis. Mengingat peran matematika yang penting ini, pembelajaran matematika yang dilaksanakan pada setiap jenjang pendidikan harus dilaksanakan sesuai dengan apa yang diharapkan, yaitu membekali siswa dengan mengembangkan kemampuan menggunakan bahasa matematika dalam mengkomunikasikan ide atau gagasan matematika untuk memperjelas suatu keadaan atau masalah.

Berdasarkan Permendiknas No. 22 tahun 2006 tentang standar isi matematika disebutkan bahwa tujuan pemebelajaran matematika disekolah yaitu, agar siswa memiliki kemampuan sebagai berikut: (1)Memahami Konsep Matematika, menjelaskan keterkaitan konsep dan mengaplikasikan konsep atau logaritma secara lues, akurat, efesien, dan tepat dalam pemecahan masalah. (2)Menggunakan penalaran pada pola dan sifat, melakukan manipulasi matematika dalam membuat generalisasi, menyusun bukti, atau menjelaskan gagasan dan pertanyaan matematika. (3)Memecahkan masalah yang meliputi kemampuan memahami masalah, merancang model matematika, menyesuaikan model, dan menafsirkan solusi yang diperoleh. (4)Mengomunikasikan gagasan dengan simbol, tabel diagram, atau media lain untuk memperjelas, keadaan atau masalah titik. (5)Memiliki sikap menghargai kegunaan matematika dalam kehidupan, yaitu memiliki rasa ingin tahu, perhatian dan minat dalam mempelajarai matematika, serta sikap ulet dan percaya diri dalam memecahkan masalah.

Berdasarkan tujuan pembelajaran matematika dilihat dari poin keempat tersebut, jelas bahwa salah satu kemampuan yang harus dimiliki siswa adalah kemampuan komunikasi matematis.Suhendra (2015: 722) mendefinisikan kemampuan komunikasi matematis adalah suatu kemampuan untuk mengungkapkan ide atau gagasan matematis dengan bahasa sendiri.Setiap siswa memiliki cara yang berbeda-beda dalam menyampaiakan atau menyelesaikan permasalahan dalam matematika, ada yang begitu mudah memahami gambargambar, simbol, atau siswa hanya berfokus dengan hapalan rumus-rumus matematika. Ketika guru mampu mengenali kemampuan komunikasi matematis siswa, maka akan lebih mudah untuk mengarahkan siswa dalam belajar.

Melalui pembelajaran matematika siswa diharapkan dapat mengkomunikasikan gagasan dengan simbol, tabel, diagram atau media lain untuk memperjelas keadaan atau masalah karena banyak persoalan ataupun informasi disampaikan dengan bahasa matematika, misalnya menyajikan persoalan atau masalah ke dalam model matematika yang dapat berupa diagram, persamaan matematika, grafik ataupun tabel.Kemampuan komunikasi sangat dibutuhkan sehingga siswa dapat mengaplikasikannya dalam proses pemecahan masalah. 
Proses pemecahan Masalah sendiri merupakan salah satu tujuan dalam pembelajaran Matematika, namun kenyataan yang ada dilapangan justru jauh berbeda dengan teori yang ada. Tidak hanya dalam kemampuan komunikasinya, tujuan lain dalam pembelajaran matematika juga belum seluruhnya mencapai sasaran yang diinginkan. Begitu banyak kesenjangan yang terjadi antara teori dengan tujuan pembelajaran matematika itu sendiri dengan praktik yang ada dilapangan.

Salah satu kesenjangan yang ada yaitu, diketahui bahwa tingkat kemampuan komunikasi matematis siswa berada pada kategori rendah. Diketahui bahwa hasil skor prestasi matematika siswa Indonesia yaitu 386, dimana skor rata-rata internasional yaitu 500, menempatkan siswa Indonesia pada peringkat ke-38 dari 42 negara yang berpartisipasi (Ina, 2012:42). Dari skor prestasi matematika di atas menunjukkan bahwa siswa Indonesia berada dalam kategori rendah dimana siswa hanya memiliki kemampuan dasar matematika saja, siswa dapat menyelesaikan permasalahan-permasalahan matematika namun hanya dalam konteks yang sederhana. Rendahnya skor yang dimiliki Negara Indonesia maupun Negara lainnya yang tidak mencapai rata-rata adalah karena disebabkan kurangnya penerapan pemahaman dalam situasi yang lebih kompleks sehingga mereka tidak mampu menyelesaikan masalah langkah demi langkah dan juga kurang mampu mengkomunikasikan pemahaman mereka dalam berbagai situasi (Ina, 2012:42).Hal serupa juga dapat dilihat dari kemampuan siswa dalam menggunakan simbol matematika dan struktur-strukturnya untuk menyajikan ide, dari banyaknya siswa yang menjawab soal yang menuntut mereka berkomunikasi secara tertulis, yaitu 27 siswa, hanya 12 orang siswa yang mampu menjawab soal dengan benar dan lengkap (Humonggio, 2013:3).

Hal ini juga didukung dengan kenyataan yang ada dilapangan, dimana peneliti melakukan wawancara dengan guru bidang studi matematika di MTs Islamiyah Medan, sebagian siswa memiliki kemampuan komunikasi matematis yang masih rendah dalam pelajaran matematika. Dari informasi yang didapatkan,diperoleh keterangan bahwa kurangnya kemampuan komunikasi matematis siswa dapat dilihat dari ketika siswa dihadapkan pada suatu soal cerita, masih banyak siswa yang kesulitan dalam menentukan langkah awal apa yang harus dilakukan dari informasi yang terdapat dalam soal, siswa tidak terbiasa menuliskan apa yang diketahui dan apa yang ditanyakan dari soal sebelum menyelesaikannya, sehingga siswa sering salah dalam menafsirkan maksud dari soal tersebut. Selain itu, siswa juga masih kurang paham terhadap suatu konsep matematika dan kurangnya ketepatan siswa dalam menyebutkan simbol atau notasi matematika. Ada banyak faktor yang menyebabkan rendahnya kemampuan komunikasi matematissiswa diantaranya, siswa kurang mampu menghubungkan gambar, diagram kedalam ide dan simbol matematika. Juga masih banyaknya siswa yang kurang antusias terhadap pembelajaran matematika.

Dalam pembelajaran matematika Kemampuan komunikasi matematis sangat penting untuk dikembangkan dalam diri siswa itu sendiri, yang Perlu diingat bahwa Matematika bukan alat untuk sekedar berpikir, tetapi juga alat untuk menyampaikan ide yang jelas dan tepat.Komunikasi matematis merupakan aspek yang sangat penting yang harus dimiliki siswa bila ingin berhasil dalam 
studi nya, sehingga komunikasi matematis memang perlu ditumbuhkembangkan di kalangan siswa (Umar, 2012: 1). Oleh karena itu, matematika harus disampaikan sebagai suatu bahasa yang bermakna. sedangkan di luar aspek pembelajaran matematika sendiri, yaitu dalam lingkup kehidupan sehari-hari kita selalu berkomunikasi untuk menjalani kehidupan yang bersosial ini. Komunikasi antara satu dengan yang lainya adalah kunci utama untuk membangun kehidupan yang lebih baik, tanpa komunikasi tidak akan mungkin terjadinya pertukaran pola pikir untuk kemajuan bangsa ini. Sehingga diharapkan para peserta didik mampu berkomunikasi dengan baik dan benar ketika berinteraksi dengan individu lainya dalam lingkungan tempat tinggalnya dan dalam konteks matematika itu khususnya.

Berdasarkan uraian latar belakang di atas, peneliti tertarik untuk menulis menelitian dengan judul: "Analisis Kemampuan Komunikasi Matematis Siswa Pada Materi Penyajian Data di Kelas VII MTs Islamiyah Medan T.P. 2017/208”

\section{B. Metode Penelitian}

Jenis penelitian ini adalah penelitian kualitatif,tujuan penelitian ini adalah untuk memperoleh deskripsi kemampuan komunikasi matematis siswa kelas VII pada pembelajaran matematika.

Penelitian ini dilakukan di MTs Islamiyah Medan yang beralamatkan di Jl. Suluh No.71D, Sidorejo Hilir, Medan Tembung, Kota Medan. Waktu penelitian yaitu pada semester genap tahun pelajaran 2017/2018 di kelas VII.

Pada penelitian ini yang menjadi subjek penelitian adalah siswa-siswi kelas VIIMTs Islamiyah Medan, pada semester genap tahun pelajaran 2017/2018.Penelitian ini menggunakan teknik penentuan subjek dengan kriteria tertentu (purposif). Adapun beberapa kriteria penentuan subjek dalam penelitian ini adalah:

1. Siswa dengan kemampuan tinggi, sedang dan rendah.

2. Siswa yang mempunyai sifat terbuka.

3. Siswa yang memiliki Kemampuan berbicara/komunikasi yang baik.

Pengumpulan data kualitatif menggunakanwawancara, observasi dan pengkajian dokumen saling mendukung dan melengkapi dalam memenuhi data yang diperlukan sebagaimana fokus penelitian (Syahrum, 2016: 142). Dalam penelitan ini peneliti menerapkan prosedur pengumpulan data sebagai berikut:

1. Observasi. Observasi dilakukan untuk mengamati obyek penelitian, yaitu untuk mangamati jalannya proses pembelajaran matematika serta mengadakan pertimbangan kemudian melakukan penilaian.

2. Wawancara.Wawancara dilakukan untuk mengumpulkan data mengenai kemampuan komuikasi matematis siswa.pelaksanaan wawancara dalam penelitian ini adalah wawancara berbasis tes. Tes yang dimaksud adalah tes tertulis terkait kemampuan komunikasi berdasarkan indikator NCTM, sehingga kemampuan komunikasi siswa akan dapat diteliti lebih dalam pada wawancara tersebut.

3. Dokumentasi. Dokumentasi dibutuhkan untuk memperoleh data mengenai nama-nama dan daftar nilai rapor semester gasal tahun ajaran 
Nursyahbany Sitorus Pane, Indra Jaya, Mara Samin Lubis: Analisis Kemampuan Komunikasi Matematis Siswa pada Materi Penyajian Data di Kelas VII MTs Islamiyah Medan T.P 2017/2018

2017/2018 dan rekaman video atau foto selama proses pembelajaran matematika berlangsung dan rekaman suara saat melakukan wawancara pendalaman kemampuan komunikasi matematis subjek oleh peneliti.

Setelah data dikumpulkan, langkah selanjutnya adalah menganalisis data. Analisis dilakukan secara mendalam pada siswa tentang kemapuan komunikasi matematisnya. Proses analisis data dimulai dengan menelaah seluruh data yang tersedia dari berbagai sumber, yaitu wawancara, pengamatan yang sudah dituliskan dalam catatan lapangan, dokumen pribadi, dokumen resmi, gambar, foto dan sebagainya. Analisis data dilakukan terbatas pada apa yang dikerjakan siswa (baik lisan maupun tulisan) (Moleong, 2013: 265).

Miles dan Huberman mengemukakan bahwa aktivitas dalam analisis data kualitatif dilakukan secara interaktif dan berlangsung secara terus menerus sampai tuntas, sehingga datanya sudah jenuh. Aktivitas dalam analisis data, yaitu data reduction, data display, dan conclusion drawing/verification(Syahrum, 2016: 148)

1. Reduksi Data

Tahap-tahap mereduksi data dalam penelitan ini adalah sebagai berikut: a) Mengumpulkan data nilai matematika siswa pada semester ganjil, b) Mengumpulkan data tes kemampuan komunikasi matematika siswa, c) Memilih subjek wawancara, kemudian melakukan wawancara, d) Mentranskip hasil wawancara, e) Menganalisis data hasil tes kemampuan komunikasi matematika,

2. Penyajian data

Bentuk penyajian data dalam penilian ini menelitian ini meliputi: a) Penyajian hasil pekerjaan siswa, 2) Penyajian hasil wawancara, 3) Penyajian hasil dokumentasi

3. Penarikan Kesimpulan/verifikasi

Kesimpulan dalam penelitian kualitatif yang diharapkan adalah merupakan temuan baru yang sebelumnya belum pernah ada. Temuan dapat berupa deskripsi atau gambaran suatu obyek yang sebelumnya masih remangremang atau gelap sehingga setelah diteliti menjadi jelas, dapat berupa hubungan kasual atau interaktif, hipotesis atau teori.

Langkah selanjutnya dalam penelitian kualitatif yaitu pemeriksaan keabsahan data. Dalam penelitian kualitatif faktor keabsahan data sangat diperhatikankarena suatu hasil penelitian tigdak ada artinya jika tidak mendapatkan pengakuan atau terpercaya. Dalam penelitian ini akan digunakan teknik kredibilitas, transferbilitas, dependabilitas, dan konfirmabilitas yang terkait dengan proses pengumpulan dan analisis data.

1. Kredibilitas (Derajat kepercayaan)

Adapun usaha untuk membuat lebih terpercaya (credible) proses, intrepretasi dan temuan dalam penelitian ini dengan cara: a) Ketekunan pengamatan (Persistent observation), b) Melakukan triangulasi (triangulation), c) Mendiskusikan dengan teman sejawat, d) Kecukupan referansi, dan e) Analisis kasus negatif. 
2. Transferabilitas (Transferability)

Transferabilitas yaitu memperhatikan kecocokan arti fungsi unsur-unsur yang terkandung dalam fenomena studi dan fenomena lain diluar ruang lingkup studi. Cara yang ditempuh untuk menjamin keteralihan (transferability) ini adalah dengan melakukan uraian rinci dari data ke teori, atau dari kasus ke kasus lain, sehingga pembaca dapat menerapkannya dalam konteks yang hampir sama (Syahrum, 2016: 168).

3. Dependabilitas (Dependability)

Dependability dalam penelitian kualitatif dapat dilakukan dengan mengkonsultasikan keseluruhan proses atau kegiatan penelitian kepada pembimbing, promotor atau konsultan(Syahrum, 2016: 169).

4. Konfirmabilitas (Confirmability)

Kegiatan komfirmabilitas (confirmabilityi) berarti menguji hasil (Product) penelitian, dikaitkan dengan proses yang dilakukan (Sugiyono, 2012:149)

\section{Hasil Penelitian}

\section{Analisis Kualitatif}

Analisis kemampuan komunikasi matematis tiap-tiap subjek didasarkan pada 3 indikator kemampuan komunikasi matematis yaitu:

Indikator 1, kemampuan mengekspresikan ide-ide matematis melalui lisan, tulisan, dan mendemonstrasikannya serta menggambarkannya secara visual. Hal ini dapat dilihat dari kemampuan siswa menuliskan informasi yang diketahui dan ditanya, serta kemampuan siswa dalam menggambarkan dan memberikan keterangan pada gambar yang sesuai dengan soal.

Indikator 2, kemampuan memahami, menginterpretasikan, dan mengevaluasi ide-ide matematis secara tertulis, maupun dalam bentuk visual lainnya. Hal ini dapat dilihat ketika siswa dapat menuliskan konsep rumus yang akan digunakan dalam menyelesaikan soal disertai dengan langkah-langkah yang benar serta perhitungan yang benar.

Indikator 3, kemampuan dalam menggunakan istilah-istilah, notasi-notasi matematika dan struktur-strukturnya untuk menyajikan ide-ide, menggambarkan hubungan-hubungan dengan model-model situasi. Hal ini dapat dilihat dari kemampuan siswa menggunakan simbol-simbol dan istilah-istilah saat menuliskan informasi yang diketahui dan saat proses pengerjaan, dan dapat dilihat ketika siswa dapat menuliskan kesimpulan jawaban yang sesuai dengan soal.

Subjek penelitian dapat dikatakan mampu untuk tiap indikator di atas jika mereka mampu menuliskan dengan lengkap dan benar tentang hal-hal yang dapat menyatakan indikator di atas. Mereka dikatakan kurang mampu jika mereka dapat menuliskan hal-hal yang dapat menyatakan indikator tetapi kurang lengkap atau ada beberapa kesalahan. Mereka dikatakan belum mampu untuk tiap indikator jika mereka tidak dapat menuliskan hal-hal yang dapat menyatakan indikator tersebut.

Urutan dalam melakukan analisis yaitu (1) melakukan analisis hasil tes kemampuan komunikasi matematis, (2) melakukan analisis hasil wawancara tes kemampuan komunikasi matematis, (3) melakukan triangulasi berdasarkan hasil tes kemampuan komunikasi matematis dan hasil wawancara. Pada urutan dalam melakukan analisis hasil tes. 
Analisis hasil tes dan wawancara disajikan dalam 3 macam kemampuan komunikasi matematika siswa, yaitu kemampuan komunikasi matematika dari siswa dengan kemampuan matematika tinggi, sedang dan rendah.

\section{Pembahasan Penelitian}

Berdasarkan hasil penelitian dan analisis data yang telah dilakukan diperoleh pembahasan mengenai deskripsi kemampuan komunikasi matematika siswa kelas VII MTs Islamiyah Medan T.P 2017/2018 pokok bahasan penyajian data sebagai berikut:

\section{a. Kemampuan komunikasi matematis siswa dengan kemampuan matematika tinggi}

Siswa dengan kemampuan matematika tinggi pada umumnya memilik kemampuan komunikasi matematika yang lebih baik dari siswa dengan kemampuan matematika sedang maupun rendah. Siswa mampu mengekspresikan, memahami, menginterpretasikan, mengevaluasi dan menggunakan istilah, simbol, notasi dan strukturnya untuk menyajikan ide matematika meskipun tidak sempurna. Sejalan dengan Ramdani, komunikasi matematika adalah kemampuan untuk berkomunikasi yang meliputi kegiatan penggunaan keahlian menulis, menyimak, menelaah, meginterpretasikan, dan mengevaluasi ide, simbol, istilah, serta informasi matematika yang diamati melalui proses mendengar, mempresentasi, dan diskusi.

Pada Indikator 1 Dilihat dari analisis pada hasil jawaban siswa dengan kemampuan matematika tinggi, ESY maupun SP memiliki kemampuan komunikasi matematika yang cukup baik dalam menyelesaikan soal materi penyajian data. Siswa dengan kemampuan tinggi mampu mengungkapkan ide matematika secara lisan namun kurang mampu mengekspresikannya melalui tulisan dengan baik. Hal ini didukung oleh pendapat Darkasyi, bahwa Komunikasi matematis mencakup komunikasi tertulis maupun lisan atau verbal. Komunikasi tertulis dapat berupa penggunaan kata- kata, gambar, tabel, dan sebagainya yang menggambarkan proses berpikir siswa. Komunikasi tertulis juga dapat berupa uraian pemecahan masalah atau pembuktian matematika yang menggambarkan kemampuan siswa dalam mengorganisasi berbagai konsep untuk menyelesaikan masalah. Sedangkan komunikasi lisan dapat berupa pengungkapan dan penjelasan verbal atau gagasan matematika. Komunikasi lisan dapat terjadi melalui interaksi antar siswa misalnya dalam pembelajaran dengan setting diskusi kelompok. Dalam menyelesaikan kelima soal, ESY dan SP mengetahui informasi apa yang diketahui dan ditanyakan soal dengan baik namun mereka tidak menuliskannya secara lengkap dan tidak menuliskannya dalam bentuk model matematika yang baik pula, hal ini disebabkan karena siswa tidak terbiasa untuk menulis dengan langkah-langkah yang sistematis dala setiap penyelesaian soalnya.

Pada indikator 2 Berdasarkan analisis hasil penelitian, siswa dengan kemampuan tinggi mampu memahami dan mengiterpretasikan ide matematika namun belum mampu mengevaluasinya dengan baik. Sejalan dengan itu Darkasyi menyatakan kemampuan komunikasi matematika siswa mencerminkan seberapa jauh pemahaman matematika dan letak konsep matematika siswa. Hal ini dijumpai oleh ESY dan SP dalam menyelesaikan soal nomor 4. Pada soal nomor 
4, tepatnya dalam membuat diagram garis. ESY dan SP mampu menentukan strategi yang benar dalam menenyelesaikan soal tersebut, namun pada langkah terakhir ESY dan SP melakukan kesalahan sehingga gambar yang diperolehnya kurang tepat. Kesalahan ini terjadi karena ESY dan SP tidak teliti dalam mengurutkan data untuk menyelesaikan soal tersebut. Selanjutnya, pada soal nomor 5, SP juga mampu menentukan strategi yang tepat dalam menyelesaikan soal tersebut namun SP belum menyelesaikan beberapa langkah terakhirnya sehingga SP belum memperoleh hasil yang tepat. Dan pada soal no 2 baik ESY dan SP belum mampu memberikan penyelesaian dari soal tersebut.

Pada indikator 3 Siswa dengan kemampuan matematika tinggi mampu menggunakan istilah, simbol, notasi dan strukturnya untuk menyajikan ide matematika namun siswa tidak memberikan kesimpulan akhir pada jawabannya. Dalam menyelesaikan soal, ESY dan SP telah menggunakan beberapa simbol dan notasi untuk menyajikan ide matematika. Sejalan dengan itu NCTM mengungkapkan salah satu standar kemampuan komunikasi matematika yaitu menggunakan bahasa matematika untuk mengekspresikan ide-ide matematika secara benar. Sedangkan bahasa matematika itu sendiri dapat berupa notasi, simbol-simbol dan sebagainya. Hal ini didukung oleh pernyataan Fathani, bahwa matematika dapat dipandang sebuah bahasa, karena dalam matematika terdapat sekumpulan lambang atau simbol dan kata (baik kata dalam bentuk lambang, misalnya ' $\geq$ ' yang melambangkan kata "lebih besar atau sama dengan", maupun kata yang diadopsi dari bahasa biasanya seperti kata "fungsi", yang dalam matematika menyatakan suatu hubungan dengan aturan tertentu, antara unsurunsur dalam dua buah himpunan). ESY dan SP juga mampu menjelaskan maksud dari sebuah data yang disajikan dalam tabel, namun ESY dan SP belum mapu memberikan kesimpulan akhir dari setiap pekerjaan yang mereka lakukan dikarenakan guru tidak membiasakan siswa untuk selalu menulis kesimpulan jawaban dari setiap soalnya.

Berdasarkan pembahasan di atas, kemampuan komunikasi matematis siswa dengan subjek siswa berkemampuan tinggi dapat dikategorikan cukup baik. Hal tersebut dikarenakan siswa yang berkemampuan tinggi dapat menuliskan bentuk representasi matematis berupa rumus-rumus yang digunakan dalam menyelesaikan permasalahan matematika. Siswa yang berkemampuan tinggi juga menunjukkan penggunaan bahasa matematika dengan baik yaitu dengan menuliskan simbol-simbol matematika meski belum sempurna, dalam menuliskan penyelesaian permasalahan matematika Siswa yang berkemampuan tinggi juga dapat menyajikan data yang sesuai dan dapat memberikan alur pikirannya meski pun belum menuliskan langkah-langkahnya dengan runtut, serta dapat menggunakan berbagai bentuk representasi yaitu dengan melakukan perhitungan meski belum terbiasa menuliskan kesimpulan disetiap akhir menyelesaikan soal.

Dari penjelasan tersebut, sebaiknya guru dalam melakaukan pembelajaran selalu menghimbau siswa agar lebih rajin menuliskan yang diketahui dan ditanyakan. Selain itu guru juga harus mengingatkan siswa untuk membiasakan menggunakan simbol-simbol matematika dalam menyajikan ide-ide matematika dan menyelesaikan permasalahan dalam matematika, serta guru juga harus mengingatkan siswa untuk selalu menuliskan urutan data yang tepat dan selalu mengingatkan untuk menuliskan kesimpulan pada setiap permasalahan. 
Nursyahbany Sitorus Pane, Indra Jaya, Mara Samin Lubis: Analisis Kemampuan Komunikasi Matematis Siswa pada Materi Penyajian Data di Kelas VII MTs Islamiyah Medan T.P 2017/2018

\section{b. Kemampuan komunikasi Matematis Siswa dengan Kemampuan Matematika Sedang}

Siswa dengan kemampuan matematika sedang pada umumnya memiliki kemampuan komunikasi matematika pada tingkat sedang. Berdasarkan hasil tes dan wawancara dapat diketahui bahwa siswa tersebut belum mampu menguasai salah satu indikator kemampuan komunikasi matematika dan pada dua indikator lainnya dapat mereka capai meskipun tidak secara sempurna. Dilihat dari analisis hasil penelitian, tidak terdapat perbedaan pencapaian indikator pada siswa dengan kemampuan matematika sedang.

Pada Indikator 1 Subjek RUE dan RF dalam mengekspresikan ide matematikanya dengan cara yang hampir sama. RUE dan RF mampu mengungkapkan ide matematika secara lisan dengan baik, RUE dan RF mengetahui informasi apa yang diketahui dan ditanyakan soal dengan baik namun tidak menuliskannya dengan lengkap. RUE dan RF ini memiliki cara yang berbeda dari subjek lainya mereka mengekspresikan ide matematika dalam bentuk gambar, hal ini terlihat ketika subjek RUE dan RF menyajikan informasi yang diketahui soal no 2 dalam bentuk tabel. Sejalan Darkasyi, Komunikasi tertulis dapat berupa penggunaan kata- kata, gambar, tabel, dan sebagainya yang menggambarkan proses berpikir siswa.

Pada indikator 2 Berdasarkan analisis hasil penelitian, siswa dengan kemampuan sedang mampu memahami dan mengiterpretasikan ide matematika namun belum mampu mengevaluasinya dengan baik. Hal ini juga dijumpai olehRUE dan RF dalam menyelesaikan soal nomor 4. Pada soal nomor 4, tepatnya dalam membuat diagram garis. ESY dan SP mampu menentukan strategi yang benar dalam menenyelesaikan soal tersebut, namun pada langkah terakhirRUE dan RF melakukan kesalahan sehingga gambar yang diperolehnya kurang tepat. Kesalahan ini terjadi karena RUE dan RF tidak teliti dalam mengurutkan data untuk menyelesaikan soal tersebut. Selanjutnya, pada soal nomor 2, RUE dan RF belum mampu menentukan strategi yang tepat dalam menyelesaikan soal tersebut juga belum mampu memberikan penyelesaianya.

Pada indikato 3 subjek RUE dan RF cukup mampu menggunakan istilah, simbol, notasi dan strukturnya untuk menyajikan ide matematika secara tertulis, namun belum mampu menyajikanya secara lisan. RUE dan RF tidak memberikan kesimpulan akhir pada jawabannya. Dalam menyelesaikan soal, RUE dan RF telah menggunakan beberapa simbol dan notasi untuk menyajikan ide matematika.

Berdasarkan pembahasan di atas, kemampuan komunikasi matematis siswa dengan kemampuan sedang dapat dikategorikan cukup baik. Hal tersebut dikarenakan siswa berkemampuan sedang dapat menuliskan bentuk representasi matematis berupa rumus-rumus yang digunakan dalam menyelesaikan permasalahan matematika. Siswa berkemampuan sedang juga menunjukkan penggunaan bahasa matematika dengan cukup baik yaitu dengan menuliskan simbol-simbol matematika dalam menuliskan penyelesaian permasalahan matematika walaupun belum mampu menyampaikan secara lisan. Siswa berkemampuan sedang juga dapat menggambarkan menyajikan data yang sesuai untuk beberapa soal. Selain itu subjek siswa berkemampuan sedang dapat memberikan alur pikirannya dengan jelas meskipun belum menuliskan langkahlangkah penyelesaian dengan rinci, serta dapat menggunakan berbagai bentuk 
representasi yaitu dengan melakukan perhitungan meski belum mampu menuliskan kesimpulan dari setiap penyelesaian soal.

Dari penjelasan tersebut, sebaiknya guru dalam melakaukan pembelajaran selalu menghimbau siswa agar lebih rajin menuliskan yang diketahui dan ditanyakan. Selain itu guru juga harus mengingatkan siswa untuk membiasakan menggunakan simbol-simbol matematika dalam menyajikan ide-ide matematika dan menyelesaikan permasalahan dalam matematika, serta guru juga harus mengingatkan siswa untuk selalu menuliskan urutan data yang tepat dan selalu mengingatkan untuk menuliskan kesimpulan pada setiap permasalahan.

\section{c. Kemampuan komunikasi Matematis Siswa dengan Kemampuan Matematika Rendah}

Siswa dengan kemampuan matematika rendah pada umumnya memiliki kemampuan komunikasi matematika pada tingkat lebih rendah dibandingkan siswa dengan kemampuan matematika tinggi maupun sedang. Berdasarkan hasil tes dan wawancara dapat diketahui bahwa siswa dengan kemampuan matematika rendah kurang mampu menguasi indikator-indikator kemampuan komunikasimatematika dengan baik.

Pada indikator 1 siswa dengan kemampuan matematika rendah pada umumnya kurang mampu mengeksresikan ide matematikanya dengan baik. Dalam menyelesaikan soal Subjek AH tidak menunjukkan ekspresi ide matematikanya. AH tidak menunjukkan gagasan, model-model matematika maupun gambargambar sebagi ekspresi ide matematikanya pada penyelesaiannya, hanya pada soal no 1 AH menuliskan informasi yangditanyakan dan pada soal no $3 \mathrm{AH}$ menuliskan informasi yang diketahui. Sedangkan subjek AA menunjukkan ekspresi ide matematikanya walaupun hanya pada satu soal. Pada soal nomor 3, AA mampu menuliskan Informasi yang diketahui dan informasi yang ditanyakan.

Pada indikato 2 siswa dengan kemampuan matematika rendah kurang mampu memahami, menginterpretasikan dan mengevaluasi ide-ide matematikanya dengan baik. Subjek AH mampu memahami dan mengiterpretasikan ide matematika namun belum mampu mengevaluasinya dengan baik. Hal ini juga dijumpai olehSubjek AH dalam menyelesaikan soal nomor 4. Pada soal nomor 4, tepatnya dalam membuat diagram garis. Subjek AH mampu menentukan strategi yang benar dalam menenyelesaikan soal tersebut, namun pada langkah terakhirSubjek $\mathrm{AH}$ melakukan kesalahan sehingga gambar yang diperolehnya kurang tepat. Kesalahan ini terjadi karena Subjek AH tidak teliti dalam mengurutkan data untuk menyelesaikan soal tersebut, begitupun pada soal no 5 subjek AH melakukan keslahaan dalam membuat diagram batang, subjek AH menyajikan data dalam bentuk histogram. Selanjutnya, pada soal nomor 2, Subjek AH belum mampu menentukan strategi yang tepat dalam menyelesaikan soal tersebut juga belum mampu memberikan penyelesaianya. Sementara untuk subjek AA sendiri belum mampu memahami dan mengiterpretasikan ide matematikanya, hal ini terlihat dari lembar jawaban AA tidak ada satu soal pun yang dapat diselesaikan oleh subjek AA. Termasuk pada soal no 1 subjek AA tidak menuliskan berpa jumlah frekuensi yang sudah disajikanya dalam tabel. Hal ini didukunng oleh teori Ansari yang menyebutkan "Lima aspek-aspek komunikasi matematis, yaitu: representasi (representating), 
mendengar (listening), membaca (reading), diskusi (discussing), dan menulis (writing). Sehinnga dapat disimpulkan bahwa subjek AA tidak mampu memenuh aspek kelima dari komunikasi matematis itu sendiri.

Pada indikator 3 Subjek AH mampu mampu menggunakan istilah, simbol, notasi dan strukturnya untuk menyajikan ide matematikanya meskipun tidak Semuanya. Subjek AH mampu memberikan kesimpulan akhir pada jawabannya. Sedangkan AA tidak mampu menjelaskan bebarapa istilah matematika pada materi penyajian data .

Dari pembahasan di atas, kemampuan komunikasi matematis siswa dengan siswa berkemampuan rendah dapat dikategorikan kurang baik. hal tersebut dikarenakan siswa kemampuan rendah cukup dalam menunjukkan penggunaan bahasa matematika dan bentuk representasi matematis. Hal ini dapat dilihat dari siswa kemampuan rendah subjek AA tidak menuliskan informasi yang ditanya dengan lengkap dan tidak mampu memberikan penyelesaian pada soal. Siswa kemampuan rendah kurang dapat memberikan alur pikiran yang jelas pada subjek AH untuk no 2, dan pada subjek AA untuk no 2 sampai 5.

Dari penjelasan tersebut, sebaiknya guru dalam melakaukan pembelajaran selalu menghimbau siswa agar lebih rajin menuliskan yang diketahui dan ditanyakan. Selain itu guru juga harus mengingatkan siswa untuk membiasakan menggunakan simbol-simbol matematika dalam menyajikan ide-ide matematika dan menyelesaikan permasalahan dalam matematika, serta guru juga harus mengingatkan siswa untuk selalu menuliskan urutan data yang tepat dan selalu mengingatkan untuk menuliskan kesimpulan pada setiap permasalahan.

\section{Keterangan:}

Untuk menjaga privasi subjek penelitian, maka subjek dalam penelitian kualitatif menggunakan kode nama siswa. adapun yang menjadi subjek penelitia yaitu: ESY, SP, RUE, RF, AH, dan AA.

\section{Kesimpulan dan Saran}

\section{Kesimpulan}

Berdasarkan hasil penelitian, diperoleh penjelasan kemampuan komunikasi matematika siswa dalam menyelesaikan soal matematika materi Penyajian Data pada kelas VII MTs Islamiyah Medan tahun anjaran 2017/2018 sebagai berikut.

a. Kemampuan komunikasi matematis siswa kelas VII MTs Islamiyah Medan secara umum dikatakan Kurang baik. hal tersebut dikaranakan sebagian besar siswa belum memenuhi beberapa indikator dari kelima indikator kemampuan komunikasi matematis.

b. Kemampuan komunikasi matematika siswa dengan kemampuan matematika tinggi.Siswa dengan kemampuan matematika tinggi pada umumnya memiliki kemampuan komunikasi matematika yang lebih baik dari siswa dengan kemampuan matematika sedang maupun rendah. Siswa mampu menyelesaikan soal dengan baik. Selain itu, siswa mampu mencapai hampir seluruh indikator kemampuan komunikasi matematika. Siswa dengan kemampuan komunkasi matematika tinggi hampir mampu 
mengekspresikan dan mengevaluasi ide matematikanya dengan baik dan mampu memahami, serta menggunakan istilah, simbol, notasi dan strukturnya untuk menyajikan ide matematika dengan baik.

c. Kemampuan komunikasi matematika siswa dengan kemampuan matematika sedang.Siswa dengan kemampuan komunikasi sedang, hampir mampu mengekspresikan ide matematikanya dengan baik serta mampu memahami, menginterpretasikan, dan mengevaluasi ide matematikanya dengan baik. Siswa dengan kemampuan matematika sedang belum mampu menggunakan istilah, notasi, simbol den strukturnya untuk menyajikan ideide matematikanya dengan baik.

d. Kemampuan komunikasi matematika siswa dengan kemampuan matematika rendah. Siswa dengan kemampuan matematika rendah pada umumnya memiliki kemampuan komunikasi matematika pada tingkat lebih rendah dibandingkan siswa dengan kemampuan matematika siswa tinggi maupun sedang. Siswa belum mampu menunjukkan ekspresi ide matematikanya melalui tulisan dengan baik, belum mampu memahami, menginterpretasikan, dan mengevaluasi ide matematika, serta belum mampu menggunakan istilah, notasi, simbol dan strukturnya untuk menyajikan ide-ide matematika dengan baik.

\section{Saran}

Berdasarkan hasil penelitian yang telah dilakukan maka dengan ini diberikan beberapa saran antara lain:

a. Bagi sekolah

Pihak sekolah hendaknya memperhatikan kemampuan komunikasi matematika siswa dan upaya untuk meningkatkan kemampuan komunikasi matematika siswa dengan menyediakan media yang efektif serta buku pelajaran yang bermutu yang dapat menunjang terlaksananya pembelajaran secara efektif, sehingga mampu meningkatkan kemampuan komunikasi matematika siswa.

b. Bagi guru

Dengan diketahuinya deskripsi kemampuan komunikasi matematika siswa diharapkan guru dapat menentukan pendekatan, strategi dan model pembelajaran matematika yang tepat untuk merencanakan serta melaksanakan proses pembelajaran yang dapat meningkatkan kemampuaan komunikasi matematika siswa baik dalam pembelajaran. Serta membiasakan siswa untuk menuliskan kembali apa-apa yang telah disampaikan pada setiap kegiatan pembelajaran berlangsung. Guru juga sebaiknya memberikan pemahaman kepada peserta didik untuk menuliskan simbol-simbol (notasi-notasi) matematika, menuliskan informasi yang diketahui dan ditanya danmenuliskan kesimpulan pada akhir penyelesaian dari suatu masalah yang telah ditemukan.

c. Bagi siswa

Dengan adanya penelitian ini diharapkan siswa mampu mengembangkan kemampuan komunikasi dalam pembelajaran matematika dan sebagai pemicu dalam meningkatkan prestasi siswa, selain itu dapat membuat siswa lebih aktif, kreatif dan mampu mengembangkan ketrampilannya dalam belajar, sehingga hasil belajar yang diperoleh akan maksimal. 
Nursyahbany Sitorus Pane, Indra Jaya, Mara Samin Lubis: Analisis Kemampuan Komunikasi Matematis Siswa pada Materi Penyajian Data di Kelas VII MTs Islamiyah Medan T.P 2017/2018

d. Bagi peneliti lain

Penelitian ini diharapkan menjadi kajian dan pengembangan penelitian lanjutan pada tempat maupun subjek lain dengan materi yang sama maupun berbeda. Dengan catatan sekurang-kurangnya dalam penelitian ini hendaknya direfleksikan untuk diperbaiki.

\section{DAFTAR PUSTAKA}

Engkoswara dan Aan Komariah. 2015. Administrasi Pendidikan, Bandung: Alfabeta.

Humonggio, Ingko. 2013. Deskripsi kemampuan komunikasi matematika siswa pada materi kubus dan balok di kelas VIII SMP Negeri 1 Tibawa. Jurnal Matematika Universitas Negeri Gorontalo.

Ina V . S Mullis, at. al. 2012, TIMSS 2011 International Result in Mathematics, (USA : TIMSS \& PIRLS International Study Centre, 2012).

Moleong. 2013. Metodologi Penelitian Kualitatif Edisi Revisi. Bandung: Remaja Rosdakarya Offset.

Sugiyono. 2012. Metode Penelitian Administrasi. Bandung: Alfabeta.

Suhendra. 2015. Pengembangan Kurikulum dan Pembelajaran Matematika. Jakarta: Universitas Terbuka.

Syahrum, dan Salim. 2015. Metodologi Penelitian Kualitatif. Bandung: Citapustaka Media.

Umar, Wahid. 2012. "Membangun Kemampuan Komunikasi Matematis dalam Pembelajaran Matematika". Infinity, Jurnal Ilmiah Program Studi Matematika STKIP : Vol.1 no.1 Tahun 2012. 